\title{
ANTIDEPRESSANT-LIKE ACTIVITY OF FLOWERS OF TECOMELLA UNDULATA IN MICE SUBJECTED TO CHRONIC UNPREDICTABLE MILD STRESS
}

\author{
DINESH DHINGRA*, DEEPAK \\ Department of Pharmaceutical Sciences, Guru Jambheshwar University of Science and Technology, Hisar, Haryana, India. \\ Email: din_dhingra@yahoo.com
}

Received: 07 July 2018, Revised and Accepted: 06 September 2018

\section{ABSTRACT}

Objective: Flowers of Tecomella undulata have been reported to be a rich source of flavonoids such as rutin and quercetin. The present study was designed to evaluate the effect of ethanol extract of flowers of T. undulata on chronic unpredictable mild stress (CUMS)-induced depression in Swiss young male albino mice.

Methods: The mice were subjected to CUMS for 21 successive days. Ethanol extract of the flowers (50, 100, and 200 mg/kg, p.o.) and fluoxetine ( $20 \mathrm{mg} / \mathrm{kg}$, p.o.) per se was administered for 21 successive days to separate groups of unstressed and stressed mice. Tail suspension test (TST) and sucrose preference test were used to evaluate the effect of the extract on depression-like behavior in mice.

Results: Extract of flowers of T. undulata $(100$ and $200 \mathrm{mg} / \mathrm{kg}$ ) significantly decreased immobility period of stressed mice in TST, indicating significant antidepressant-like activity of the extract. Stress-induced reduced sucrose preference was significantly restored by the extract. There was no significant effect on locomotor activity of mice by the extract and fluoxetine. The extract significantly reversed stress-induced increase in brain malondialdehyde levels; plasma nitrite and corticosterone levels; and also significantly reversed the stress-induced decrease in reduced glutathione and catalase levels. There was no significant effect of the extract on brain MAO-A activity in both unstressed and stressed mice.

Conclusion: These results indicated that ethanol extract of flowers of T. undulata showed significant antidepressant-like activity in mice subjected to CUMS, probably through alleviation of oxidative stress and decrease in plasma corticosterone levels.

Keywords: Antidepressant, Chronic unpredictable mild stress, Depression, Tail suspension test, Tecomella undulata

(C) 2019 The Authors. Published by Innovare Academic Sciences Pvt Ltd. This is an open access article under the CC BY license (http://creativecommons. org/licenses/by/4. 0/) DOI: http://dx.doi.org/10.22159/ajpcr.2019.v12i1.28981

\section{INTRODUCTION}

Depression is a psychiatric disorder characterized by symptoms such as low mood, loss of interest in normal activities, anhedonia, feeling of worthlessness, sleep disturbances, and suicidal tendencies [1]. The proportion of the global population with depression in 2015 was estimated to be $4.4 \%$. As per the report of the World Health Organization, $4.5 \%$ population of India suffered from depression in the year 2015 [2]. Depression occurs mainly due to monoaminergic neurotransmitter imbalances (such as serotonin, norepinephrine, and dopamine) [3], oxidative and nitrosative stress [4]. The monoamine hypothesis explains that depletion of monoamines in the limbic system, hippocampus, and frontal cortex is responsible for depression [5]. In addition to monoamine hypothesis, depression may also be due to hypersecretion of corticotrophin-releasing hormone and impairment in response to glucocorticoids [6]. There is hyperactivity of hypothalamicpituitary-adrenal (HPA) axis in around 50\% of depressed patients ( $80 \%$ if severely depressed). When chronic stress is subjected to animals, the same change in hyperactivity of the HPA axis has been observed [7]. Stress has an important role in the development of human depression [8]. Laboratory animals subjected to chronic unpredictable mild stress (CUMS) develop depressive symptoms similar to human depression $[9,10]$. CUMS-induced increase in brain oxidative stress is considered as a major factor for neurotoxicity and neuronal death, which may be responsible for the development of chronic stressinduced depression [11].

Current antidepressant drugs, which target monoamines, only produce remission in 30\% of depressive persons [12] and most of the antidepressants cause a variety of side effects. Thus, there is a need to identify newer and safer natural antidepressants. Hypericum perforatum has been proven to be an effective antidepressant in clinical studies [13]. Tecomella undulata (Family: Bignoniaceae) is commonly known as Rohida (in Hindi) or Dadimapuspaka (in Sanskrit) [14]. This plant holds tremendous potential of medicinal value and is used in traditional and folklore system of medicines. T. undulata bark has been reported to possess hepatoprotective [15], antimicrobial [16], antiobesity [17], antifungal [18], and immunomodulatory [19] activities. Leaves of T. undulata have been reported to possess antiHIV [20], antidiabetic, and antioxidant [21,22] activities, while the whole plant of T. undulata has been reported to possess analgesic and anti-inflammatory [23] activities. Bark of T. undulata has been reported to contain lapachol [24]. Flowers of this plant have not been evaluated for any pharmacological activity. Further, flowers of this plant are rich source of flavonoids $(3.2 \mathrm{mg} / \mathrm{g}$ ) such as rutin, quercetin, and luteolin 7 -glucoside [25,26]. Rutin [27] and quercetin [28] have been reported to possess antidepressant activity in laboratory animals. Rutin has been reported to be present in both flowers and leaves [25] of this plant, but flowers of this plant contain both rutin and quercetin [26]. Due to the presence of flavonoids such as rutin and quercetin in flowers of T. undulata, the flowers of this plant might possess antidepressant potential. Hence, the present study was designed to evaluate the effect of ethanol extract of T. undulata flowers on CUMS -induced depression in mice.

\section{METHODS}

Drugs and chemicals

Fluoxetine (Psychotropic India Limited, Haridwar, India), N-(1Naphthyl) ethylenediamine dihydrochloride, p-nitroso-N,Ndimethylaniline, 5-hydroxytryptamine creatinine sulfate monohydrate, thiobarbituric acid (HiMedia Laboratories Private Limited, Mumbai, 
India), sulfanilamide, meta-phosphoric acid, potassium ferricyanide, hydrogen peroxide, trichloro acetic acid (CDH Private Limited, New Delhi, India), 5,5, Dithiobis-2-(nitro benzoic acid) (SRL Private Limited, Mumbai, India), sulfosalicylic acid (Spectrochem Private Limited, Mumbai, India), and total protein estimation kit (Siemens Ltd., Vadodara, Gujarat, India) were employed in the present study. Fluoxetine was dissolved in normal saline $(0.9 \% \mathrm{w} / \mathrm{v}$ sodium chloride). Ethanol extract of flowers of T. undulata was suspended in $1 \% \mathrm{w} / \mathrm{v}$ carboxy methyl cellulose.

\section{Plant material}

The flowers of T. undulata were collected in April 2016 from the Village - Rambass, District - Bhiwani, Haryana (India). The plant was identified as T. undulata Sm. (Seem), Family - Bignoniaceae by Dr. Anjula Pandey, Principal Scientist, Economic Botany, Division of Plant Exploration and Germplasm Collection, ICAR-National Bureau of Plant Genetic Research (NBPGR), PUSA Campus, New Delhi - 110012 (Reference no. NHCP/ NBPGR/2016-9). The collected plant material was shade dried, coarsely powdered and used for further studies.

\section{Preparation of ethanol extract}

Shade-dried coarsely powdered flowers (500 g) of T. undulata were defatted using petroleum ether for $24 \mathrm{~h}$. Defatted flowers were extracted in $70 \% \mathrm{v} / \mathrm{v}$ ethanol using Soxhlet assembly at $100^{\circ} \mathrm{C}$ for $22 \mathrm{~h}$ [25]. The solvent was then evaporated under vacuum, and the dried extract was stored in a refrigerator.

\section{Gas chromatography-mass spectroscopy (GC-MS) analysis of extract}

The ethanol extract of flowers of T. undulata $(50 \mathrm{mg} / \mathrm{mL})$ was injected $(1 \mu \mathrm{L})$ into gas chromatogram GCMS-QP2010 Plus computerized system (Shimadzu Corporation, Kyoto, Japan) using an auto-injector (AOC-20i) connected with it. For separation of components, Rtx-5MS (crossband, 5\% diphenyl/95\% dimethyl polysiloxane) capillary column (Restek Corporation, Bellefonte, USA) with dimensions $30 \mathrm{~m}$ (length) $\times$ $0.25 \mathrm{~mm}$ (diameter) $\times 0.25 \mu \mathrm{m}$ (film thickness) was used. GC-MS spectra were obtained using the following conditions: Interface temperature $260^{\circ} \mathrm{C}$, ion source temperature $230^{\circ} \mathrm{C}$, solvent cutoff time $2.5 \mathrm{~min}$, and ionization mode - electronic impact at $70 \mathrm{eV}$ and $\mathrm{m} / \mathrm{z}$ range 40-990. Carrier gas used was helium (>99.999\%) with flow rate of $1.21 \mathrm{~mL} / \mathrm{min}$ in split mode (10:1). Injection temperature was $250^{\circ} \mathrm{C}$, and the sample injection volume was $1.0 \mu \mathrm{L}$. Programmed oven temperature was $100^{\circ} \mathrm{C}$ for $3 \mathrm{~min}$ and then increased to $280^{\circ} \mathrm{C}$ at a rate of $10^{\circ} \mathrm{C} / \mathrm{min}$ and held at $280^{\circ} \mathrm{C}$ for the next $19 \mathrm{~min}$. Constituents in the ethanol extract of flowers of T. undulata were identified by their retention index which was determined relative to the alkane homologous series injected with the sample. The GC solution software post run analysis option and compound responsible for each peak were confirmed by matching their mass fragmentation patterns to the National Institute of Standard Technology Library and Wiley Library.

\section{Experimental animals}

Swiss male albino mice (3 months old, weighing around 22-30 g) were purchased from Disease Free Small Animal House, Lala Lajpat Rai University of Veterinary and Animal Sciences, Hisar (Haryana, India). Female sex hormone (estrogen) has been found to possess antidepressant activity [29], so the female mice were excluded from the present study, and only male mice were used. Animals were housed separately in groups of 7-8 per cage (polypropylene cage size: $29 \mathrm{~cm} \times$ $22 \mathrm{~cm} \times 14 \mathrm{~cm})$ in an air-conditioned room $\left(24^{\circ}-26^{\circ} \mathrm{C}\right)$ with alternating light and dark cycle of $12 \mathrm{~h}$ each. The animals had free access to food and water, except feed was withdrawn $2 \mathrm{~h}$ before and $2 \mathrm{~h}$ after drug administration. The animals were acclimatized for at least 5 days before behavioral experiments which were carried out between 09:00 and 17:00 h. The experimental protocol was approved by Institutional Animals Ethics Committee (IAEC) in its meeting held on November 23, 2016 (vide letter number-IAEC/2016/26-34, dated December 5, 2016). Animal care was taken as per the guidelines of committee for the purpose of control and supervision of experiments on animals
(CPCSEA), Ministry of the environment, forests and climate change, Government of India (Registration No. CPCSEA/436/PO/Re/S/2001).

\section{Selection of doses}

The doses $(50,100$, and $200 \mathrm{mg} / \mathrm{kg})$ of ethanol extract of flowers of T. undulata were selected. The dose $(20 \mathrm{mg} / \mathrm{kg})$ of fluoxetine was selected based on the literature [30].

\section{CUMS procedure}

Mice were subjected to CUMS as followed earlier in our lab. [31]. Animals were subjected to stress paradigm once a day over a period of 3 weeks between 10:00 and 17:00 h. The order of stressors was as follows:

\begin{tabular}{llllllll}
\hline Weeks & Day-1 & Day-2 & Day-3 & Day-4 & Day-5 & Day-6 & Day-7 \\
\hline 1 & $\mathrm{I}$ & $\mathrm{F}$ & $\mathrm{E}$ & $\mathrm{O}$ & $\mathrm{T} 1$ & $\mathrm{X}$ & $\mathrm{T} 2$ \\
2 & $\mathrm{I}$ & $\mathrm{X}$ & $\mathrm{O}$ & $\mathrm{T} 2$ & $\mathrm{~F}$ & $\mathrm{~T} 1$ & $\mathrm{E}$ \\
3 & $\mathrm{O}$ & $\mathrm{F}$ & $\mathrm{T} 1$ & $\mathrm{X}$ & $\mathrm{T} 2$ & $\mathrm{I}$ & $\mathrm{E}$ \\
\hline
\end{tabular}

I-Immobilization for $2 \mathrm{~h}, \mathrm{~F}$-Exposure to foreign object for $24 \mathrm{~h}$ (e.g., piece of plastic), E-Exposure to empty water bottles for $1 \mathrm{~h}, \mathrm{O}$ - overnight illumination, T1-tail pinch (30 s), X-Tilted cage at $45^{\circ}$ for $7 \mathrm{~h}, \mathrm{~T} 2$-tail pinch $(60 \mathrm{~s})$

\section{Tail suspension test (TST)}

The TST is a behavioral test widely used for evaluating antidepressantlike activity of a drug [32]. In this test, mice were individually suspended $50 \mathrm{~cm}$ above the surface of a floor, using an adhesive tape placed $1 \mathrm{~cm}$ away from the tip of the tail. Each animal under test was both acoustically and visually isolated from other animals during the test. The total period of immobility was recorded manually for 6 min. Animal was considered to be immobile when it did not show any body movement, hung passively, and completely motionless. The observer was blind to various treatments.

\section{Sucrose preference test}

Sucrose preference test [9] was employed herein to determine anhedonia, one of the core symptoms of major depression in humans. The procedure was composed of training and testing sessions. After 1 week of acclimatization, mice were trained to consume $1 \%(\mathrm{w} / \mathrm{v})$ sucrose solution before the start of the CUMS protocol. During training period, mice were deprived of food and water for $48 \mathrm{~h}$ and only exposed to $1 \%(\mathrm{w} / \mathrm{v})$ sucrose solution. 3 days later, after 23 -h food and water deprivation, 1-h baseline test was performed, in which mice could select between two pre-weighed bottles, one with $1 \%(\mathrm{w} / \mathrm{v})$ sucrose solution and the other with tap water. Then, the sucrose preference was calculated according to the following formula:

Sucrose preference $(\%)=A / A+B \times 100$

Where A is sucrose solution intake in grams and B is water intake in grams.

The test was again performed on the $22^{\text {nd }}$ day to evaluate the effect of stress as well as drug treatment.

\section{Measurement of locomotor activity}

To rule out the effects of various drug treatments on locomotor activity of mice, horizontal locomotor activities of control and test animals were recorded for a period of $5 \mathrm{~min}$ [33] using photoactometer (INCO, Ambala, India).

\section{Experimental protocol}

The animals were divided into following 20 groups, each having 7-8 mice.

\section{Groups for TST}

Groups $1-5$ ( $\mathrm{n}=8$ each group): Vehicle $(1 \% \mathrm{w} / \mathrm{v} \mathrm{CMC})$, ethanol extract of flowers of T. undulata $(50,100$, and $200 \mathrm{mg} / \mathrm{kg})$, and fluoxetine (20 mg/kg), respectively, were administered orally to mice for 21 
successive days. The mice were subjected to TST 60 min after vehicle/ drug administration on $22^{\text {nd }}$ day, and then the mice were tested for locomotor activity using photoactometer.

Groups 6-10: Vehicle (1\% w/v CMC; $n=8$ each group), ethanol extract of flowers of T. undulata $(50,100$, and $200 \mathrm{mg} / \mathrm{kg} ; \mathrm{n}=7$ each), and fluoxetine (20 mg/kg; $\mathrm{n}=8$ ), respectively, were administered orally 30 min before induction of stress to mice for 21 successive days. The mice were subjected to TST 60 min after vehicle/drug administration on the $22^{\text {nd }}$ day, which was followed by testing of locomotor activity of mice using photoactometer

\section{Groups for sucrose preference test}

Groups 11-20 (n=8 each group): Separate mice were employed for sucrose preference test, but their treatments were same as mentioned under Groups 1-10.

\section{Biochemical estimations}

\section{Collection of blood samples}

After behavioral testing of unstressed and stressed mice of Groups 1-10 on $22^{\text {nd }}$ day and $1 \mathrm{~h}$ after drug administration on $23^{\text {rd }}$ day, mice were sacrificed by cervical dislocation and blood sample $(1.0-1.5 \mathrm{~mL})$ was withdrawn from carotid artery. Plasma was separated using refrigerated centrifuge (Remi, Mumbai, India) at $2500 \mathrm{rpm}$ for $10 \mathrm{~min}$. The plasma was used for estimation of nitrite and corticosterone levels.

\section{Estimation of plasma nitrite levels}

Plasma nitrite levels were measured as per the reported method [34].

\section{Estimation of plasma corticosterone levels}

The quantitative estimation of corticosterone levels in plasma was performed as per the reported method [35].

\section{Biochemical estimations in brain homogenate}

After withdrawing blood samples on the $23^{\text {rd }}$ day, the brain of mice was isolated. The collected brain samples were washed with cold $0.25 \mathrm{M}$ sucrose - $0.1 \mathrm{M}$ Tris-0.02 M ethylenediamine tetra-acetic acid buffer ( $\mathrm{pH}$ 7.4) and weighed. The buffer washed brain sample was homogenized in 9 volumes of cold $0.25 \mathrm{M}$ sucrose - $0.1 \mathrm{M}$ Tris- $0.02 \mathrm{M}$ ethylenediamine tetra-acetic acid buffer $\mathrm{pH} 7.4$ buffer and centrifuged twice at $2500 \mathrm{rpm}$ for $10 \mathrm{~min}$ at $4^{\circ} \mathrm{C}$ in a cooling centrifuge (Remi Instruments, Mumbai, India). The pellet was discarded. The supernatant was then centrifuged at 12,000 rpm for $20 \mathrm{~min}$ at $4^{\circ} \mathrm{C}$ in a cooling centrifuge. This centrifuged supernatant was separated into two parts:

- Part I: The precipitates (mitochondrial fraction) were used for estimation of MAO-A activity.

- Part II: The remaining supernatant was used to assay lipid peroxidation, glutathione (GSH), and catalase levels.

\section{Measurement of MAO-A activity}

MAO-A activity was assessed spectrophotometrically [36,37].

\section{Estimation of protein concentration}

Total protein concentration was estimated in the brain homogenate using a total protein kit(Siemens, Siemens Ltd., Vadodara, Gujarat), using semi-automatic AutoAnalyzer (Chem5 plus-V2 semi-AutoAnalyzer; Erba Mannheim, Germany). Total protein concentration was estimated by Biuret method at $546 \mathrm{~nm}$ wavelength. The procedure followed was as same as mentioned in the pamphlet supplied along with the kit [38].

\section{Estimation of lipid peroxidation}

The thiobarbituric acid-reactive substances (TBARS), a measure of lipid peroxidation were assayed as per the reported method [39].

\section{Estimation of reduced GSH}

GSH was assayed as per the reported method [40].

\section{Estimation of catalase activity}

Catalase activity was assayed as per the reported method [41].
Statistical analysis

All the results are expressed as mean \pm SEM, data were analyzed by analysis of variance (ANOVA) followed by Tukey-Kramer multiple comparison test using GraphPad Instat, version 3.05. $\mathrm{p}<0.05$ was considered statistically significant.

\section{RESULTS}

\section{GC-MS analysis of extract}

In GC-MS analysis of ethanol extract of flowers of T. undulata, 83 components were detected (Table 1). Some important constituents detected include Vitamin E (0.41\%), beta-sitosterol (3.68\%), squalene, ethyl palmitate, and benzoic acid.

Effect of ethanol extract of flowers of T. undulata and fluoxetine on immobility periods of mice in TST

Exposure of the mice to unpredictable mild stress for 21 successive days significantly $(\mathrm{p}<0.05)$ increased immobility time period as compared to unstressed mice. Ethanol extract of flowers of T. undulata (100 and $200 \mathrm{mg} / \mathrm{kg}$, p.o.) and fluoxetine (20 mg/kg, p.o.) per se administered for 21 successive days significantly decreased immobility period of stressed mice ( $\mathrm{p}<0.05, \mathrm{p}<0.01$, and $\mathrm{p}<0.001$, respectively) as compared to vehicle-treated stressed mice. The extract did not produce any significant effect on immobility period of unstressed mice as compared to vehicle-treated unstressed mice. However, fluoxetine significantly decreased immobility period of unstressed mice (Fig. 1).

Effect of ethanol extract of flowers of $T$. undulata and fluoxetine on sucrose preference test

Exposure of the mice to unpredictable mild stress for 21 successive days significantly $(\mathrm{p}<0.05)$ decreased sucrose preference $(\%)$ as compared to unstressed mice. There was no significant difference in sucrose preference (\%) among all the groups in the baseline test. Ethanol extract of flowers of T. undulata $(50,100$, and $200 \mathrm{mg} / \mathrm{kg}$ ) administered for 21 successive days did not show any significant change in sucrose preference in unstressed mice. However, fluoxetine $(20 \mathrm{mg} / \mathrm{kg})$ administered for 21 successive days significantly increased sucrose preference of unstressed mice as compared to vehicle-treated unstressed mice. Ethanol extract of flowers of T. undulata (100 and $200 \mathrm{mg} / \mathrm{kg})$ and fluoxetine $(20 \mathrm{mg} / \mathrm{kg})$ per se significantly restored the reduced sucrose preference (\%) in stressed mice as compared to vehicle-treated stressed mice. There was no significant effect of the lowest dose $(50 \mathrm{mg} / \mathrm{kg})$ of the extract on sucrose preference of stressed mice as compared to its vehicle-treated control (Table 2)

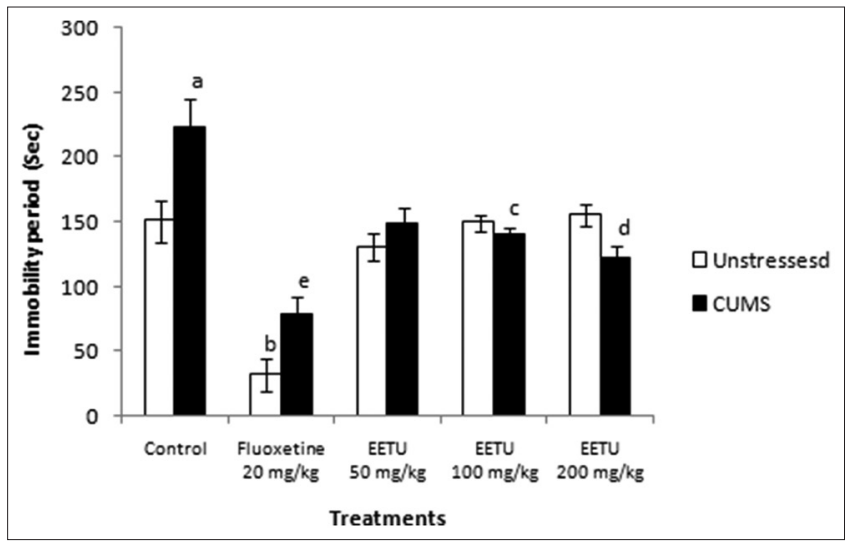

Fig. 1: Effect of ethanol extract of Tecomella undulata and fluoxetine on immobility period of mice in TST. Values are expressed as mean \pm SEM. The data were analyzed by one-way ANOVA followed by Tukey-Kramer multiple comparison tests. $F(9,67)=11.584 ; p<0.05$. ${ }^{a, b} p<0.05$ and $p<0.001$, respectively, as compared to vehicle treated unstressed mice. ${ }^{c, d, e} p<0.05$, $\mathbf{p}<0.01$, and $\mathbf{p}<0.001$, respectively, as compared to vehicle-treated stressed mice. EETU stands for ethanol extract of $T$. undulata 
Table 1: Constituents detected in ethanol extract of flowers of T. undulata

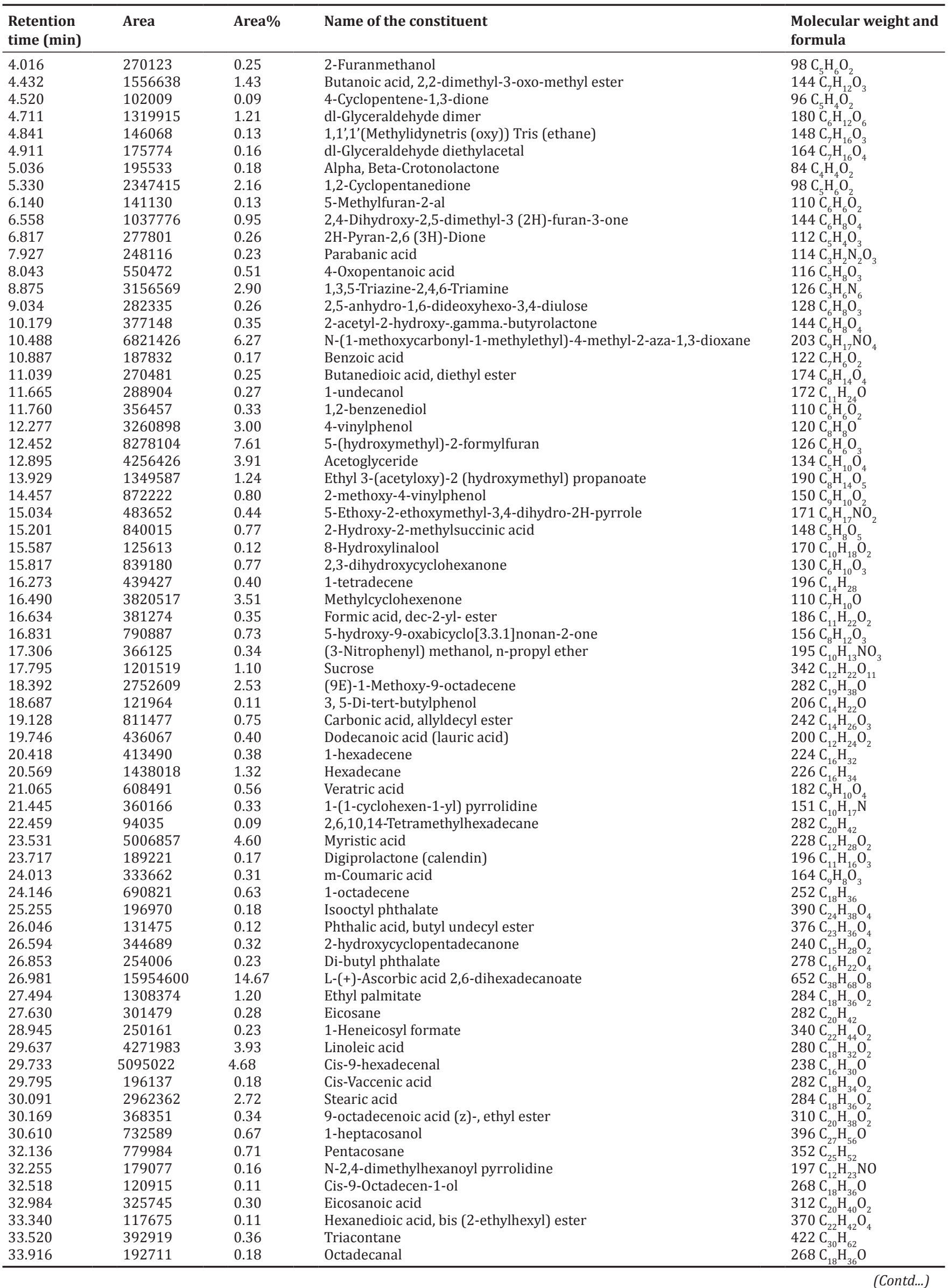


Table 1: (Continued)

\begin{tabular}{|c|c|c|c|c|}
\hline $\begin{array}{l}\text { Retention } \\
\text { time (min) }\end{array}$ & Area & Area\% & Name of the constituent & $\begin{array}{l}\text { Molecular weight and } \\
\text { formula }\end{array}$ \\
\hline 34.965 & 2161050 & 1.98 & Tetracontane & $562 \mathrm{C}_{40} \mathrm{H}_{82}$ \\
\hline 35.091 & 2599260 & 2.39 & 2-Monopalmitin & $330 \mathrm{C}_{19}^{40} \mathrm{H}_{38}^{82} \mathrm{O}_{4}$ \\
\hline 35.433 & 569033 & 0.52 & Bis (2-ethylhexyl) phthalate & $390 \mathrm{C}_{24}^{19} \mathrm{H}_{38}^{38} \mathrm{O}_{4}^{4}$ \\
\hline 39.672 & 75774 & 0.07 & Terephthalic acid, bis (2-ethylhexyl) ester & $390 \mathrm{C}_{24}^{24} \mathrm{H}_{38}^{38} \mathrm{O}_{4}^{4}$ \\
\hline 40.928 & 583255 & 0.54 & Squalene & $410 \mathrm{C}_{30}^{24} \mathrm{H}_{50}^{38}$ \\
\hline 42.212 & 890637 & 0.82 & Hexatriacontane & $506 \mathrm{C}_{36}^{30} \mathrm{H}_{74}^{50}$ \\
\hline 45.121 & 228744 & 0.21 & Stigmast-5-en-3-ol, oleate & $678 \mathrm{C}_{47}^{10} \mathrm{H}_{82} \mathrm{O}_{2}$ \\
\hline 45.553 & 275788 & 0.25 & Tetrapentacontane & $758 \mathrm{C}_{54}^{47} \mathrm{H}_{110}^{82}$ \\
\hline 45.939 & 442303 & 0.41 & Vitamin E & $430 \mathrm{C}_{29}^{54} \mathrm{H}_{50}^{110} \mathrm{O}_{2}$ \\
\hline 48.601 & 1481663 & 1.36 & Stigmasta-5,23-dien-3-beta-ol & $412 \mathrm{C}_{29}^{29} \mathrm{H}_{48}^{50} \mathrm{O}^{2}$ \\
\hline 48.819 & 388201 & 0.36 & Stigmasta-4,22-diene & $396 \mathrm{C}_{29}^{29} \mathrm{H}_{48}^{48}$ \\
\hline 50.202 & 4003715 & 3.68 & Beta-sitosterol & $414 \mathrm{C}_{29}^{29} \mathrm{H}_{50}^{48} \mathrm{O}$ \\
\hline Total & 108806812 & 100.00 & & \\
\hline
\end{tabular}

Table 2: Effect of ethanol extract of T. undulata and fluoxetine on sucrose preference (\%) in unstressed and stressed mice

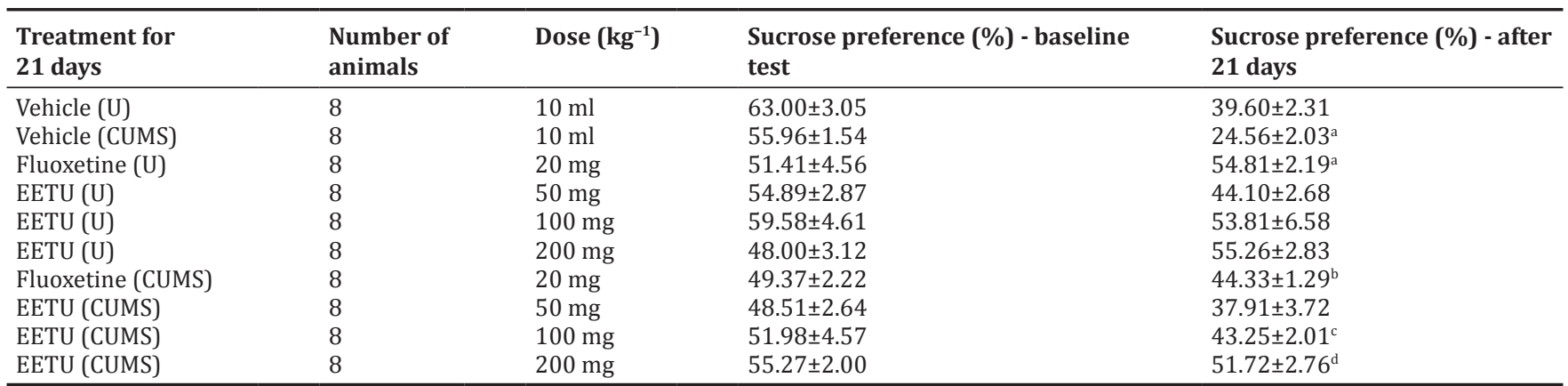

U: Unstressed mice, CUMS: Chronic unpredictable mild stress, values are expressed as mean \pm SEM. The data were analyzed by one-way ANOVA followed by TukeyKramer multiple comparison test. For sucrose preference $(\%)$ - baseline test; $F(9,67)=8.567 ; p<0.05$. For sucrose preference $(\%)$ - after 21 days; F $(9,67)=9.169$; $\mathrm{p}<0.05$. ${ }^{\mathrm{a}} \mathrm{p}<0.05$ as compared to vehicle-treated unstressed mice. ${ }^{\mathrm{b}, \mathrm{c}, \mathrm{d}} \mathrm{p}<0.05, \mathrm{p}<0.01$, and $\mathrm{p}<0.001$, respectively, as compared to vehicle-treated stressed mice. EETU stands for Ethanol extract of T. undulata

Table 3: Effect of ethanol extract of flowers of T. undulata and fluoxetine on locomotor activity of mice

\begin{tabular}{llll}
\hline $\begin{array}{l}\text { Treatment for } \\
\text { 21 days }\end{array}$ & $\begin{array}{l}\text { Number of } \\
\text { animals }\end{array}$ & Dose $\left(\mathrm{kgp}^{-1}\right)$ & $\begin{array}{l}\text { Locomotor } \\
\text { activity }\end{array}$ \\
\hline Vehicle (U) & 8 & $10 \mathrm{~mL}$ & $190.37 \pm 15.45$ \\
Vehicle (CUMS) & 8 & $10 \mathrm{~mL}$ & $242.62 \pm 20.21$ \\
Fluoxetine (U) & 8 & $20 \mathrm{mg}$ & $274.50 \pm 36.30$ \\
EETU (U) & 8 & $50 \mathrm{mg}$ & $248.37 \pm 18.24$ \\
EETU (U) & 8 & $100 \mathrm{mg}$ & $270.25 \pm 24.50$ \\
EETU (U) & 8 & $200 \mathrm{mg}$ & $250.12 \pm 21.53$ \\
Fluoxetine (CUMS) & 8 & $20 \mathrm{mg}$ & $287.50 \pm 27.87$ \\
EETU (CUMS) & 7 & $50 \mathrm{mg}$ & $291.85 \pm 22.77$ \\
EETU (CUMS) & 7 & $100 \mathrm{mg}$ & $233.71 \pm 18.81$ \\
EETU (CUMS) & 7 & $200 \mathrm{mg}$ & $246.42 \pm 27.22$ \\
\hline
\end{tabular}

U: Unstressed mice, CUMS: Chronic unpredictable mild stress. Values are expressed as mean \pm SEM. The data were analyzed by one-way ANOVA followed by Tukey-Kramer multiple comparison test. F $(9,67)=1.528$; $p<0.05$. EETU stands for ethanol extract of T. undulata

Effect of ethanol extract of flowers of T. undulata and fluoxetine on locomotor activity of mice

Various treatments did not significantly affect the spontaneous locomotor activity of unstressed and stressed mice as compared to their respective vehicle-treated controls (Table 3).

Effect of ethanol extract of flowers of T. undulata and fluoxetine on plasma nitrite levels

Plasma nitrite levels were significantly $(\mathrm{p}<0.05)$ increased in mice subjected to CUMS. Doses $(50,100$, and $200 \mathrm{mg} / \mathrm{kg}$ ) of ethanol extract of flowers of $T$. undulata administered for 21 successive days did not show any significant effect on plasma nitrite levels of unstressed mice.
However, fluoxetine significantly $(\mathrm{p}<0.05)$ decreased plasma nitrite levels in unstressed mice as compared to its control. Lowest dose (50 mg/kg) of ethanol extract of flowers of T. undulata administered for 21 successive days did not show any significant effect on plasma nitrite levels of stressed mice. However, higher doses (100 and $200 \mathrm{mg} / \mathrm{kg}$ ) of the extract of flowers and fluoxetine $(20 \mathrm{mg} / \mathrm{kg})$ administered per se for 21 successive days significantly $(\mathrm{p}<0.01, \mathrm{p}<0.01$, and $\mathrm{p}<0.001$, respectively) decreased plasma nitrite levels in stressed mice as compared to vehicle-treated stressed mice (Fig. 2).

\section{corticosterone levels}

CUMS significantly $(\mathrm{p}<0.01)$ increased plasma corticosterone levels as compared to vehicle-treated unstressed mice. Ethanol extract of flowers of T. undulata (100 and $200 \mathrm{mg} / \mathrm{kg}$ ) and fluoxetine (20 mg/kg) per se administered for 21 successive days significantly $(\mathrm{p}<0.001$, respectively) decreased the corticosterone levels of stressed mice as compared to their respective vehicle-treated control. There was no significant effect of the lowest dose $(50 \mathrm{mg} / \mathrm{kg}$ ) of the extract on corticosterone level of stressed mice as compared to its vehicletreated control. Ethanol extract of flowers of T. undulata $(50,100$, and $200 \mathrm{mg} / \mathrm{kg}$ ) administered for 21 successive days did not significantly decrease plasma corticosterone levels in unstressed mice as compared to vehicle-treated unstressed mice. However, fluoxetine significantly decreased corticosterone level of unstressed mice (Fig. 3).

Effect of ethanol extract of flowers of T. undulata and fluoxetine on brain

MAO-A activity

CUMS significantly $(\mathrm{p}<0.001)$ increased brain MAO-A activity as compared to vehicle-treated unstressed mice. Ethanol extract of flowers of T. undulata $(50,100$, and $200 \mathrm{mg} / \mathrm{kg})$ administered for 21 successive 
days did not significantly decrease MAO-A activity in unstressed and stressed mice as compared to respective vehicle-treated control. However, fluoxetine $(20 \mathrm{mg} / \mathrm{kg})$ significantly $(\mathrm{p}<0.01)$ decreased MAO-A activity in stressed mice as compared to its vehicle-treated control. There was no significant effect of fluoxetine on MAO-A activity in unstressed mice as compared to its control (Fig. 4).

Effect of ethanol extract of flowers of T. undulata and fluoxetine on brain

\section{TBARS levels (malondialdehyde equivalents)}

TBARS levels were increased significantly $(\mathrm{p}<0.05)$ in mice subjected to stress paradigm as compared to vehicle-treated unstressed mice. Ethanol extract of flowers of T. undulata (100 and $200 \mathrm{mg} / \mathrm{kg}$ ) and fluoxetine $(20 \mathrm{mg} / \mathrm{kg})$ per se administered for 21 days significantly $(\mathrm{p}<0.05, \mathrm{p}<0.001$, and $\mathrm{p}<0.05$, respectively) decreased TBARS levels in stressed mice as compared to vehicle-treated stressed mice. However, lowest dose $(50 \mathrm{mg} / \mathrm{kg})$ of ethanol extract of flowers of $T$. undulata did

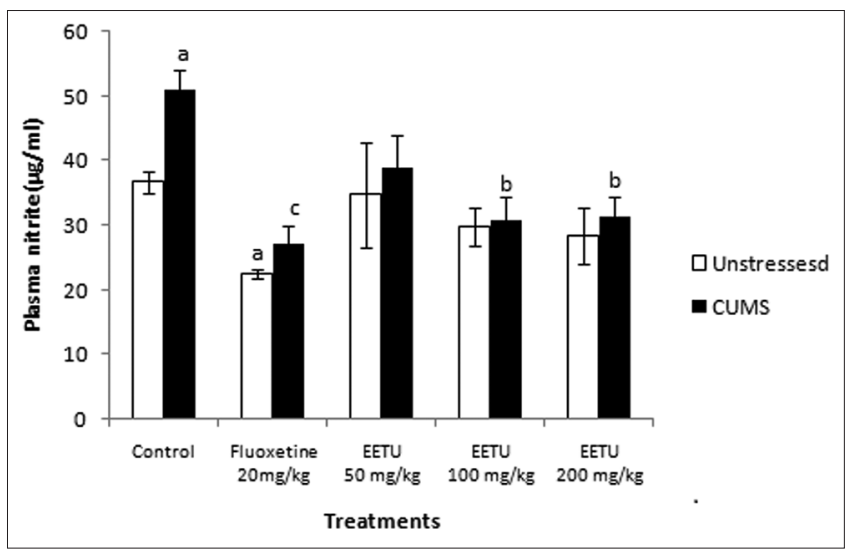

Fig. 2: Effect of ethanol extract of Tecomella undulata and fluoxetine on plasma nitrite levels in mice. Values are expressed as mean $\pm \mathrm{SEM}$. The data were analyzed by one-way ANOVA

followed by Tukey-Kramer multiple comparison tests. $F(9,67)=6.537 ; p<0.05$. ${ }^{\mathrm{a}} \mathrm{p}<0.05$, as compared to vehicle treated unstressed mice. ${ }^{b, c} p<0.01$ and $p<0.001$, respectively, as compared to vehicle-treated stressed mice. EETU stands for ethanol extract of $T$. undulata

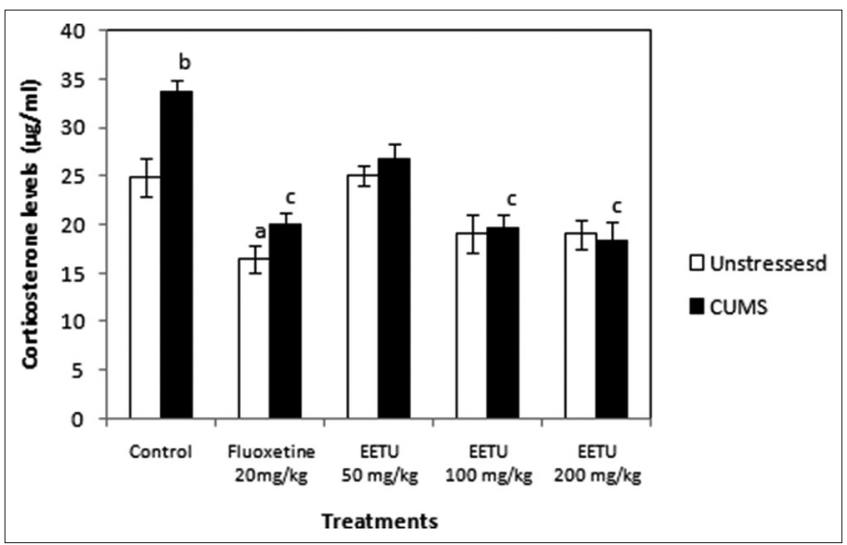

Fig. 3: Effect of ethanol extract of Tecomella undulata and fluoxetine on plasma corticosterone levels in mice. Values are expressed as mean \pm SEM. The data were analyzed by one-way ANOVA followed by Tukey-Kramer multiple comparison tests. $F(9,67)=9.398 ; p<0.05$. ${ }^{a, b} p<0.05$ and $p<0.01$, respectively, as compared to vehicle-treated unstressed mice. ${ }^{c} \mathbf{p}<0.001$ as compared to vehicle-treated stressed mice. EETU stands for ethanol extract of $T$. undulata not significantly decrease TBARS levels in stressed mice. There was no significant effect on TBARS levels in unstressed mice by ethanol extract of flowers of T. undulata (Fig. 5).

Effect of ethanol extract of flowers of $T$. undulata and fluoxetine on brain reduced GSH levels

GSH levels were significantly $(\mathrm{p}<0.001)$ decreased in stressed mice as compared to vehicle-treated unstressed mice. Lowest dose $(50 \mathrm{mg} /$ $\mathrm{kg}$ ) of ethanol extract of flowers of T. undulata administered for 21 successive days did not significantly increase GSH levels in stressed mice as compared to its vehicle-treated control. However, higher doses (100 and $200 \mathrm{mg} / \mathrm{kg}$ ) of ethanol extract of flowers of T. undulata and fluoxetine $(20 \mathrm{mg} / \mathrm{kg})$ per se administered for 21 successive days significantly $(\mathrm{p}<0.05)$ increased GSH levels in stressedmice as compared to vehicle-treated stressed mice. However, ethanol extract administered for 21 successive days did not significantly increase GSH levels in unstressed mice as compared to respective vehicletreated control. However, fluoxetine significantly increased GSH

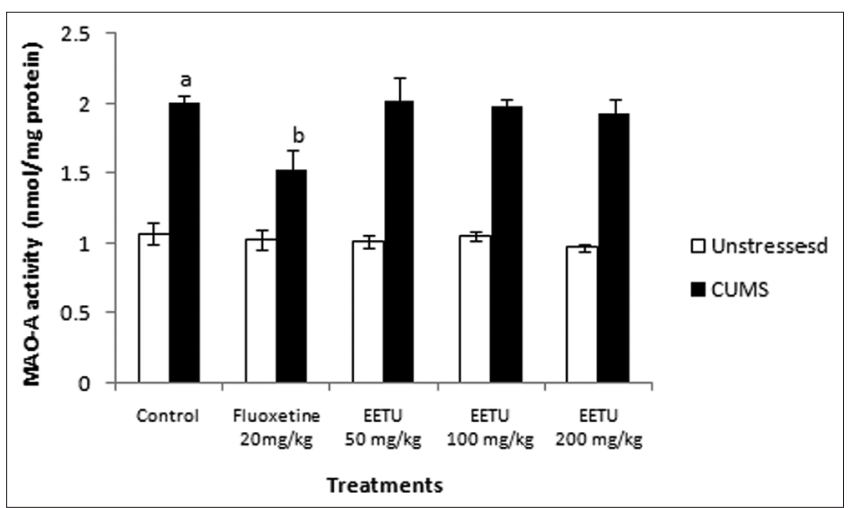

Fig. 4: Effect of ethanol extract of Tecomella undulata and fluoxetine on brain MAO- A activity in mice. Values are expressed as mean \pm SEM. The data were analyzed by one-way ANOVA followed by Tukey-Kramer multiple comparison tests. $F(9,67)=30.722 ; p<0.05$. ${ }^{a} p<0.001$ as compared to vehicletreated unstressed mice. ${ }^{\mathrm{b}} \mathbf{p}<0.01$ as compared to vehicle-treated stressed mice. EETU stands for ethanol extract of $T$. undulata

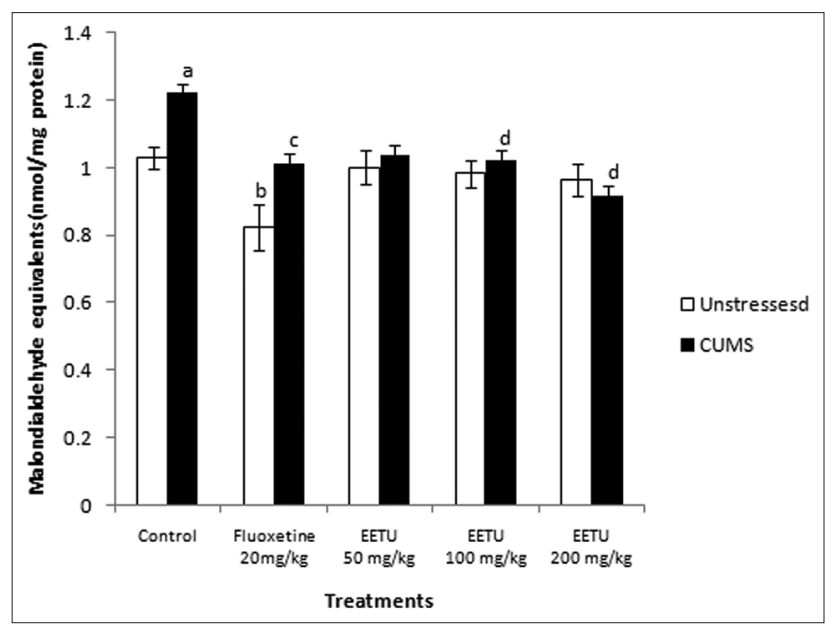

Fig. 5: Effect of ethanol extract of Tecomella undulata and fluoxetine on brain MDA equivalents in mice. Values are expressed as mean \pm SEM. The data were analyzed by one-way ANOVA followed by Tukey-Kramer multiple comparison tests. $F(9,67)=6.924 ; p<0.05 .{ }^{a, b} p<0.05$ and $p<0.01$, respectively, as compared to vehicle-treated unstressed mice. ${ }^{c, d} p<0.05$ and $\mathrm{p}<\mathbf{0 . 0 0 1}$, respectively, as compared to vehicle-treated stressed mice. EETU stands for ethanol extract of $T$. undulata 
levels in unstressed mice as compared to its vehicle-treated control (Fig. 6).

Effect of ethanol extract of flowers of $T$. undulata and fluoxetine on brain catalase activity

Catalase activity was significantly decreased in brain of stressed mice as compared to respective vehicle-treated unstressed mice. Lowest dose (50 mg/kg) of ethanol extract of flowers of T. undulata administered for 21 successive days did not significantly increase catalase levels in stressed mice as compared to its vehicle-treated control. However, higher doses (100 and $200 \mathrm{mg} / \mathrm{kg}$ ) of ethanol extract and fluoxetine $(20 \mathrm{mg} / \mathrm{kg})$ per se administered for 21 successive days significantly $(\mathrm{p}<0.05)$ increased catalase levels in stressed mice as compared to vehicle-treated stressed mice. The ethanol extract administered for 21 successive days did not significantly increase catalase levels in unstressed mice as compared to vehicle-treated unstressed mice. However, fluoxetine significantly increased catalase levels in unstressed mice as compared to its vehicle-treated control (Fig. 7).

\section{DISCUSSION}

In the present investigation, ethanol extract of flowers of $T$. undulata administered for 21 successive days showed significant antidepressantlike activity in mice subjected to CUMS. Induction of depression using CUMS is considered as the most valid animal model of depressive behavior observed in humans after long-term exposure to multiple stressors [42,43]. CUMS-induced depression model can be used for evaluating the potential antidepressants by employing behavioral tests such as TST [32] and sucrose preference test [9]. In the present study, mice that were exposed to chronic stress exhibited greater immobility periods in TST as compared to control animals, thus showed depression-like behavior. Chronic treatment with fluoxetine $(20 \mathrm{mg} / \mathrm{kg}$, p.o.) or ethanol extract of flowers of T. undulata $(100$ and $200 \mathrm{mg} / \mathrm{kg}$, p.o.) produced a significant decrease in immobility periods of stressed mice in TST, indicating significant antidepressant-like activity. However, the ethanol extract did not affect the immobility periods of unstressed mice in TST, indicating non-significant antidepressant activity of the extract in unstressed mice. The ethanol extract did not affect locomotor activity of unstressed and stressed mice as compared to their respective vehicle-treated controls, thus ruling out its CNS stimulant or depressant activity.

Another model, sucrose preference test was also employed for evaluation of ethanol extract of flowers of T. undulata on depressionlike behavior in stressed mice. This test is an indicator of anhedonia-like behavioral change, indicating loss of interest or pleasure. Anhedonia, a main symptom of human major depression, was modeled by inducing a decrease in responsiveness to reward reflected by reduced consumption and/or preference of sweetened solutions $[10,44]$. In our study, stressed mice showed a decrease in sucrose preference as compared to unstressed mice. Sucrose preference was significantly restored in stressed mice by chronic administration of fluoxetine $(20 \mathrm{mg} / \mathrm{kg}$, p.o.) or ethanol extract of the flowers $(100$ and $200 \mathrm{mg} / \mathrm{kg}$, p.o.), which further supported their antidepressant-like action. Thus, the results obtained from behavioral studies indicated that the ethanol extract produced significant antidepressant-like action in mice exposed to CUMS.

HPA axis is activated in response to stress, with resultant increase in circulating glucocorticoids such as corticosterone in rodents or cortisol in primates. Activation of HPA axis is associated with abnormally high blood glucocorticoid levels, which may eventually lead to depression [45]. Cortisol is known to regulate neuronal survival, neuronal excitability, neurogenesis, and memory acquisition, and high levels of cortisol may thus contribute to the manifestation of depressive symptoms by impairing these brain functions [46]. Chronic antidepressant treatment in rodents reduced HPA activity $[47,48]$. Thus, the restoration of normal functional status of HPA axis may be critically involved in the treatment of clinical depression [45]. CUMS-induced hyperactivity of HPA axis causes increased serum corticosterone level

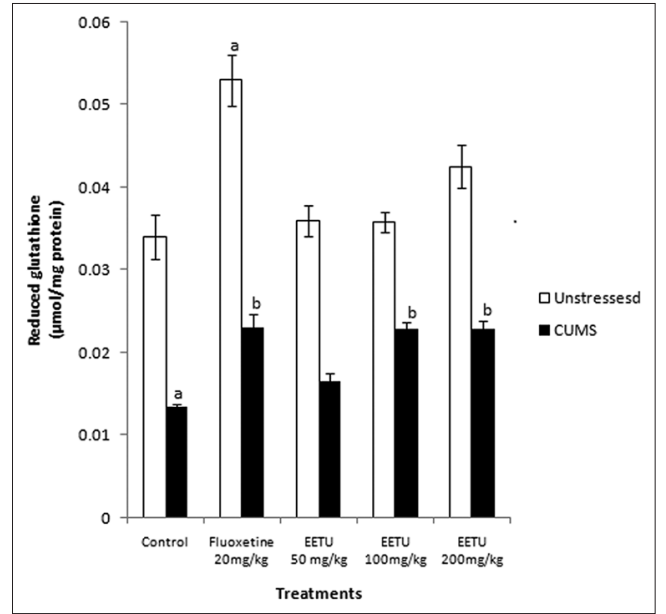

Fig. 6: Effect of ethanol extract of Tecomella undulata and fluoxetine on brain reduced GSH levels in mice.Values are expressed as mean \pm SEM. The data were analyzed by one-way ANOVA followed by Tukey-Kramer multiple comparison tests. $F(9,67)=42.609 ; p<0.05$. ${ }^{a} p<0.001$ as compared to vehicletreated unstressed mice ${ }^{\mathrm{b}} \mathbf{p}<0.05$ as compared to vehicle-treated stressed mice. EETU stands for ethanol extract of $T$. undulata

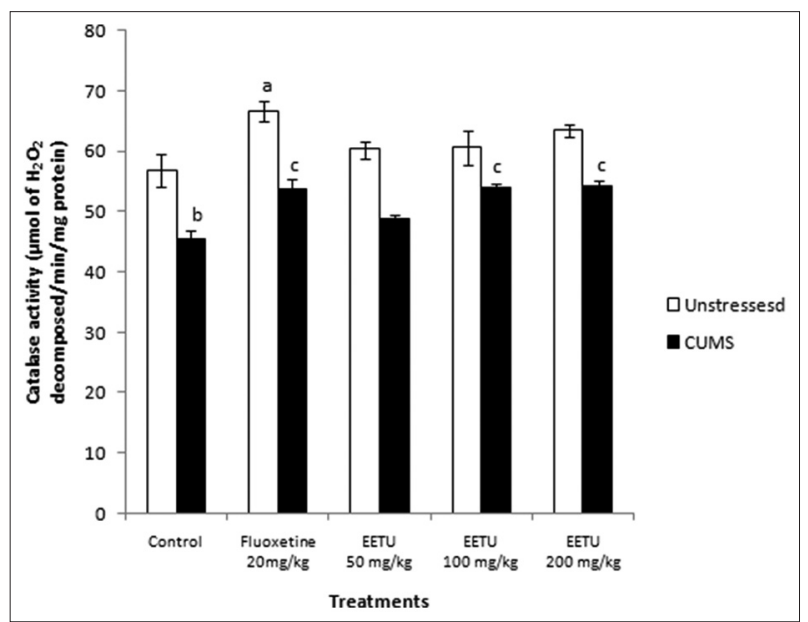

Fig. 7: Effect of ethanol extract of Tecomella undulata and fluoxetine on brain catalase activity in mice. Values are expressed as mean \pm SEM. The data were analyzed by one-way ANOVA followed by Tukey-Kramer multiple comparison tests. F $(9,67)=14.37$; $\mathbf{p}<0.05$. ${ }^{a, b} \mathbf{p}<0.01$ and $\mathbf{p}<0.001$, respectively, as compared to vehicletreated unstressed mice. ${ }^{c} p<0.05$ as compared to vehicle-treated stressed mice. EETU stands for ethanol extract of $T$. undulata

which is supported by observations from other studies [48]. Ethanol extract of flowers of T. undulata reduced CUMS-induced hyperactivity of HPA axis in mice, as indicated by significant reduction of plasma corticosterone levels. There was no significant effect on plasma corticosterone levels in unstressed mice, indicating that hyperactivity of HPA axis is observed only in stressful conditions.

Reactive oxygen species (ROS) play a role in some neuropsychiatric disorders such as major depression. Activation of immune-inflammatory process, increased monoamine catabolism, and abnormalities in lipids may cause overproduction of ROS, lipid peroxidation, and reduced antioxidant enzyme activities, and these processes may be related to depression [49,50]. In the present study, 21 days of exposure to different stressors in mice resulted in increase of brain TBARS, and plasma nitrite levels; and decrease in brain reduced GSH and catalase levels. This is supported by an earlier study form our laboratory where CUMS 
impaired the antioxidant status (increased brain lipid peroxidation and plasma nitrite levels, decreased GSH levels, and catalase activity) in brain tissue, presumably through production of excessive ROS [51]. Chronic administration of ethanol extract of the flowers $(100$ and $200 \mathrm{mg} / \mathrm{kg}$, p.o.) and fluoxetine per se showed significant decrease in brain TBARS and plasma nitrite levels; and increase in brain reduced GSH and catalase activity in stressed mice. Thus, ethanol extract of flowers of T. undulata (100 and $200 \mathrm{mg} / \mathrm{kg}$, p.o.) and fluoxetine significantly alleviated oxidative stress in mice subjected to CUMS. The antioxidant activity of ethanol extract of flowers of T. undulata is also supported by an earlier study [25]. Alleviation of oxidative stress by fluoxetine has also been reported in the literature [52]. Stressful situations in rats have also been reported to significantly increase plasma nitrite levels [53,54]. The ethanol extract (100 and $200 \mathrm{mg} / \mathrm{kg}$ ) and fluoxetine $(20 \mathrm{mg} / \mathrm{kg}$ ) per se significantly reduced nitrosative stress as indicated by reduction of the plasma nitrite levels in stressed mice as compared to vehicle-treated stressed mice. Thus, ethanol extract of flowers of T. undulata showed a strong protective effect against oxidative stress that plays a key role in CUMS -induced depression. Further, chronic exposure to different stressors led to increased activity of brain MAO-A. Chronic treatment with the ethanol extract $(50,100$, and $200 \mathrm{mg} / \mathrm{kg})$ did not significantly inhibit brain MAO-A activity in both unstressed and stressed mice, indicating that MAO-A inhibition might not be responsible for antidepressant activity of the ethanol extract. Further, antidepressant activity of the extract might be due to the presence of beta-sitosterol, which is present in the extract to the extent of 3.68\%, since antidepressant activity of beta-sitosterol has been reported in the literature [42].

\section{CONCLUSION}

Ethanol extract of flowers of T. undulata administered for 3 successive weeks showed significant antidepressant-like activity in mice subjected to CUMS probably through alleviation of oxidative stress and decrease in plasma corticosterone levels. However, further studies are required to identify the components responsible for the protective effect of ethanol extract of flowers in CUMS-induced depression.

\section{ACKNOWLEDGMENT}

The authors thank Dr. Anjula Pandey, Principal Scientist, Division of Plant Exploration and Germplasm Collection, National Herbarium of Cultivated Plants (NHCP), ICAR- National Bureau of Plant Genetic Research (NBPGR), New Delhi, for authentication of plant specimen.

\section{AUTHORS' CONTRIBUTIONS}

Author Deepak collected the literature, performed experimental studies, statistically analyzed the data, and wrote the protocol and first draft of the manuscript. Author Dinesh Dhingra designed and supervised the study; checked and finalized the manuscript.

\section{CONFLICTS OF INTEREST}

None.

\section{REFERENCES}

1. Schechter LE, Ring RH, Beyer CE, Hughes ZA, Khawaja X, Malberg JE. Innovative approaches for the development of antidepressant drugs: Current and future strategies. Neurotherapeutics 2005;2:590-611.

2. World Health Organization. Depression and Other Common Mental Disorders: Global Health Estimates. Geneva: World Health Organization; 2017. p. 1-24.

3. Manji HK, Drevets WC, Charney DS. The cellular neurobiology of depression. Nat Med 2001;7:541-7.

4. Leonard B, Maes M. Mechanistic explanations how cell-mediated immune activation, inflammation and oxidative and nitrosative stress pathways and their sequels and concomitants play a role in the pathophysiology of unipolar depression. Neurosci Biobehav Rev 2012;36:764-85.

5. Tanabe A, Nomura S, Rinsho N. Pathophysiology of depression. Nihon
Rinsho 2007;65:1585-90.

6. Pariante CM, Lightman SL. The HPA axis in major depression: Classical theories and new developments. Trends Neurosci 2008;31:464-8.

7. Young EA, Haskett RF, Murphy-Weihberg V, Watson SJ, Akil H. Loss of glucocorticoid fast feedback in depression. Arch Gen Psychiatr 1991;48:693-9.

8. Nestler EJ, Barrot M, DiLeone RJ, Eisch AJ, Gold SJ, Monteggia LM. Neurobiology of depression. Neuron 2002;34:13-25.

9. Willner P, Towell A, Sampson D, Sophokleous S, Muscat R. Reduction of sucrose preference by chronic unpredictable mild stress, and its restoration by a tricyclic antidepressant. Psychopharmacology (Berl) 1987:93:358-64.

10. Willner P. Validity, reliability and utility of the chronic mild stress model of depression: A 10-year review and evaluation. Psychopharmacology (Berl) 1997;134:319-29.

11. Madrigal JL, Olivenza R, Moro MA, Lizasoain I, Lorenzo P, Rodrigo J. Glutathione depletion, lipid peroxidation and mitochondrial dysfunction are induced by chronic stress in rat brain. Neuropsychopharmacol 2001;24:420-9.

12. O'Donnell JM, Shelton RC. Drug therapy of depression and anxiety disorders. In: Brunton LL, Chabner BA, Knollmann BC, editors. Goodman and Gilman's: The Pharmacological Basis of Therapeutics.

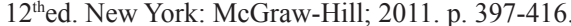

13. Rahimi R, Nikfar S, Abdollahi M. Efficacy and tolerability of Hypericum perforatum in major depressive disorder in comparison with selective serotonin reuptake inhibitors: A meta-analysis. Prog Neuropsychopharmacol Biol Psychiatry 2009;33:118-21.

14. Rohilla R, Garg M. Phytochemistry and pharmacology of Tecomella undulata. Int J Green Pharm 2014;8:1-6.

15. Singh D, Gupta RS. Hepatoprotective activity of methanol extract of Tecomella undulata against alcohol and paracetamol induced hepatotoxicity in rats. Life Sci Med Res 2011;26:1-8.

16. Danya U, Udhayasankar MR, Arumugasamy K, Baluprakash T. Bioactivity of Tecomella undulata (G. Don) Seem (FamilyBignoniaceae) on human pathogens. South Asian J Biol Sci 2012;2:71-82

17. Alvala R, Alvala M, Sama V, Dharmarajan S, Ullas JV, MR B. Scientific evidence for traditional claim of anti-obesity activity of Tecomella undulata bark. J Ethnopharmacol 2013;148:441-8.

18. Kumawat R, Sharma S, Kumar S. An overview for various aspects of multifaceted, health care Tecomella undulata seem plant. Acta Pol Pharm 2012;69:993-6.

19. Choudhary GP. Immunomodulatory activity of alcoholic extract of Tecomella undulata Linn. in mice. Asian J Pharm Biol Res 2011:1:67-70.

20. Azam MM. Anti-HIV agents and other compounds from Tecomella undulata. Orient J Chem 1999;15:375-7.

21. Kumar S, Sharma S, Vasudeva N, Ranga V. In vivo anti-hyperglycemic and anti-oxidant potentials of ethanol extract from Tecomella undulata. Diabetol Metab Syndr 2012;4:33.

22. Sharma RA, Bhardwaj R, Yadav A. Antioxidant activity of total phenolic compounds of Tecomella undulata. Int J Pharm Pharm Sci 2013;5:96-100.

23. Ahmad F, Khan RA, Rashad S. Preliminary screening of methanol extracts of Celastrus peniculatus and Tecomella undulata for analgesic and anti-inflammatory activities. J Ethnopharmacol 1994;42:193-8.

24. Richa R, Nahida S, Vidhu A. Densitometric validation of lapachol in Tecomella undulata seem bark by high-performance thin-layer chromatography. Int J Pharm Pharm Sci 2018;10:87-90.

25. Laghari AQ, Memon S, Nelofar A, Laghari AH. Tecomella undulata G. Don: A rich source of flavanoids. Ind Crops Prod 2013;43:213-7.

26. Taneja SC, Bhatnagar RP, Jiwari HP. Chemical constituents of flowers of Tecomella undulata. Indian J Chem 1975;13:427-8.

27. Machado DG, Bettio LE, Cunha MP, Santos AR, Pizzolatti MG, Brighente IM, et al. Antidepressant-like effect of rutin isolated from the ethanolic extract from Schinu smolle L. in mice: Evidence for the involvement of the serotonergic and noradrenergic systems. Eur $\mathrm{J}$ Pharmacol 2008;587:163-8.

28. Bhutada P, Mundhada Y, Bansod K, Ubgade A, Quazi M, Umathe S, et al. Reversal by quercetin of corticotrophin releasing factor induced anxiety-and depression-like effect in mice. Prog Neuropsychopharmacol Biol Psychiatry 2010;34:955-60.

29. Kandi P, Hayslett RL. Nicotine and 17b-estradiol produce an antidepressant-like effect in female ovariectomized rats. Brain Res Bull 2011;84:224-8.

30. Valecha R, Dhingra D. Antidepressant-like activity of Celastrus paniculatus seed oil in mice subjected to chronic unpredictable mild stress. Br J Pharm Res 2014;5:576-93. 
31. Dhingra D, Bansal Y. Antidepressant-like activity of beta-carotene in unstressed and chronic unpredictable mild stressed mice. J Funct Foods 2014; 7:425-34.

32. Steru L, Chermat R, Thierry B, Simon P. The tail suspension test: A new method for screening antidepressants in mice. Psychopharmacology (Berl) 1985;85:367-70.

33. Chhillar R, Dhingra D. Antidepressant-like activity of gallic acid in mice subjected to unpredictable chronic mild stress. Fundam Clin Pharmacol 2013;27:409-18.

34. Green LC, Wagner DA, Glogowski J, Skipper PL, Wishnock JS, Tannenbaum SR. Analysis of nitrate, nitrite, and [N-15N]-labelled nitrate in biological fluids. Anal Biochem 1982;126:131-8.

35. Bartos J, Pesez M. Colorimetric and fluorimetric determination of steroids. Pure Appl Chem 1979;151:2157-69.

36. Charles M, McEwan J. MAO activity in rabbit serum. In: Tabor H, Tabor CW, editors. Methods in Enzymology. Vol. 17B. New York and London: Academic Press; 1977. p. 692-8.

37. Schurr A, Livne A. Differential inhibition of mitochondrial monoamine oxidase from brain by hashish components. Biochem Pharmacol 1976;25:1201-3.

38. Henry RJ, Winkelman JW. Clinical Chemistry Principles and Techniques. New York: Harper and Row; 1974. p. 96-8.

39. Wills ED. Mechanisms of lipid peroxide formation in tissues. Role of metals and haematin proteins in the catalysis of the oxidation of unsaturated fatty acids. Biochim Biophys Acta 1965;98:238-51.

40. Jollow DJ, Mitchell JR, Zampaglione N, Gillette JR. Bromobenz induced liver necrosis: Protective role of glutathione and evidence for 3,4-bromobenzenoxide as the hepatotoxic metabolite. Pharmacol 1974;11:151-69.

41. Claiborne A. Catalase activity. In: Greenwald RA, editors. Handbook of Methods for Oxygen Radical Research. Boca Raton: CRC; 1985. p. 283-4.

42. Zhao D, Zheng L, Qi L, Wang S, Guan L, Xia Y, et al. Structural features and potent antidepressant effects of total sterols and betasitosterol extracted from Sargassum horneri. Mar Drugs 2016;14:1-11.
43. Willner P. Chronic mild stress (CMS) revisited: Consistency and behavioral-neurobiological in the effects of CMS. Neuropsychobiol 2005;52:90-110.

44. Willner P. Animal models as simulations of depression. Trends Pharmacol Sci 1991;12:131-6.

45. Pan Y, Zhang WY, Xia X, Kong LD. Effects of icariin on hypothalamicpituitary-adrenal axis action and cytokine levels in stressed spraguedawley rats. Biol Pharm Bull 2006;29:2399-403.

46. Sousa N, Cerqueira JJ, Almeida OF. Corticosteroid receptors and neuroplasticity. Brain Res 2008;57:561-70.

47. Mason BL, Pariante CM. The effects of antidepressants on the hypothalamic-pituitary-adrenal axis. Drug News Perspect 2006;19:603-8.

48. Jindal A, Mahesh R, Bhatt S. Etazolate rescues behavioral deficits in chronic unpredictable mild stress model: Modulation of hypothalamicpituitary-adrenal axis activity and brain derived neurotrophic factor level. Neurochem Int 2013;63:465-75.

49. Bilici M, Efe H, Koroglu MA, Uydu HA, Bekaroglu M, Deger O. Anti-oxidative enzyme activities and lipid peroxidation in major depression: Alterations by antidepressant treatments. J Affect Disord 2001;64:43-51.

50. Bajpai A, Verma AK, Srivastava M, Srivastava R. Oxidative stress and major depression. J Clin Diagn Res 2014;8:CC04-7.

51. Dhingra D, Bansal S. Antidepressant-like activity of plumbagin in unstressed and stressed mice. Pharmacol Rep 2015;67:1024-32.

52. Novio S, Nunez MJ, Amigo G, Freire-Garabal M. Effects of fluoxetine on the oxidative status of peripheral blood leucocytes of restrain stressed mice. Basic Clin Pharmacol Toxicol 2011;109:365-71.

53. Lee CY, Cheng HM, Sim SM. Mulberry leaves protect rat from immobilization stress-induced inflammation. Biofactors 2007;31:25-33.

54. Bhatt S, Mahesh $\mathrm{R}$, Jindal A, Devadoss $\mathrm{T}$, Dhar AK. Neuropharmacological evaluation of a novel 5- $\mathrm{HT}_{3}$ receptor antagonist (6 g) on chronic unpredictable mild stress-induced changes in behavioral and brain oxidative stress parameters in mice. Indian $\mathrm{J}$ Pharmacol 2014;46:191-6. 